\title{
Multi-objective Optimization of Friction Welding Process Parameters using Grey Relational Analysis for Joining Aluminium Metal Matrix Composite
}

\author{
Sreenivasan KONGANAPURAM SUNDARARAJAN ${ }^{1 *}$, Satish Kumar SHANMUGAM ${ }^{2}$ \\ ${ }^{1}$ Department of Mechanical Engineering, Misrimal Navajee Munoth Jain Engineering College, Chennai, Tamilnadu, \\ India -600097 \\ ${ }^{2}$ Department of Mechanical Engineering, Velammal Engineering College, Chennai, Tamilnadu, India - 600066
}

crossref http://dx.doi.org/10.5755/j01.ms.24.2.17725

Received 08 March 2017; accepted 13 July 2017

\begin{abstract}
Aluminium metal matrix composites has gained importance in recent time because of its improved mechanical and metallurgical properties. The welding of aluminium metal matrix composites using conventional welding process has got many demerits so in order to overcome them a solid state welding process is to be employed. To achieve a good strength, weld in the aluminium metal matrix composite bars an efficient and most preferred technique is friction welding. In this work the aluminium metal matrix composite AA7075 + 10\% vol SiC-T6 is selected and friction welded. The combination of friction welding process parameters such as spindle speed, friction pressure, upset pressure and burn-off- length for joining the AA7075 + $10 \%$ vol SiCP-T6 metal matrix composite bars are selected by Taguchi's design of experiment. The optimum friction welding parameters were determined for achieving improved ultimate tensile strength and the hardness using grey relational analysis. A combined grey relational grade is found from the determined grey relational coefficient of the output responses and the optimum friction welding process parameters were obtained as spindle speed $-1200 \mathrm{rpm}$, friction pressure $-100 \mathrm{MPa}$, upset pressure $-250 \mathrm{MPa}$, Burn-off-Length $-2 \mathrm{~mm}$. Analysis of variance (ANOVA) performed shows that the friction pressure is the most significant friction welding parameter that influences the both the ultimate tensile strength and hardness of friction welded AA7075 + 10\% volSiCp-T6 joints. The fractured surface under microstructure study also revealed good compliance with the grey relational grade result.

Keywords: aluminium metal matrix composite, Taguchi's design of experiments, friction welding, ultimate tensile strength, hardness, optimization, grey relational analysis, ANOVA.
\end{abstract}

\section{INTRODUCTION}

Aluminium alloys are employed in the aerospace, automotive and marine applications because of its good strength to weight ratio. Among the aluminium alloys, AA7075 alloy is the one, which has got good mechanical properties as it is strengthen by the precipitate $\mathrm{MgZn}_{2}$ and $\mathrm{Mg}_{3} \mathrm{Zn}$ due to the presence of $\mathrm{Mg}$ and $\mathrm{Zn}$ in it. Low density, good cryogenic property and good response to age hardening have attracted this alloy in the fabrication of military vehicles, storage tanks, naval and marine applications.

Aluminium Alloy metal matrix composites (AA MMCs) reinforced with ceramic particles merge the properties of the matrix with those of the ceramic reinforcement and exhibit superior properties like higher specific strength and good thermal stability when compared to the corresponding monolithic alloys [1]. However, the application of AA MMCs as structural materials has been narrower due to the demerits of the conventional welding process in making the welded joints. The foremost problem is that the aluminium matrix and its alloying elements (e.g. $\mathrm{Mg}, \mathrm{Ti}$ ) have a greater affinity towards the ceramic particles when the temperature of the joining process elevates above the melting point of the matrix alloy and as a result the embrittlement of the matrix alloy and decrease in the reinforcement and matrix strength occurs [2].
Therefore, the heat input must be kept as low as possible when joining these materials and hence the conventional fusion welding process cannot be used for effective welding of the AAMMCs. The solid state welding process like friction welding can be effectively used for welding AAMMCs as its welding temperature falls well below the melting point of the matrix metal thereby avoiding the problems associated with the fusion techniques [3,4]. Among the available solid state welding process friction welding process is an efficient and environmental friendly because of non-requirement of filler material or flux as a result no hazardous fumes are produced. During joining of two parts using friction welding process one part will be kept stationary while the other part will be rotating by rubbing the stationary part with initial friction pressure to produce heat in the interface. When the heat between the interface reaches the welding temperature, then the rotation of the workpiece should be stopped and final upset pressure is to be applied to complete the welding process.

In the friction welding process good quality of joint produced between the two rubbing surfaces can be achieved mainly by controlling the process parameters like Spindle Speed (SS), Friction Pressure (FP), Upset Pressure (UP) and Burn-off-length (BOL) [5]. The Ultimate Tensile Strength (UTS) and the Hardness (HD) of the welded joint plays a predominant role in deciding the weld quality. The Taguchi's DOE is an influential tool in quality optimization

\footnotetext{
* Corresponding author. Tel.: +91-9994543215.

E-mail address:kssreeni@gmail.com (K.S. Sreenivasan)
} 
[6]. Taguchi's technique makes use of a special design of orthogonal array $(\mathrm{OA})$ to study the required characteristics through a minimum number of experiments. Grey relational analysis is a simple and powerful statistical tool used for multiple objective performance characteristics to obtain the best parameter combination [7-9].

In this paper grey relational analysis is used to predict the optimum combination of the friction welding process parameters to achieve good UTS and HD during welding of $\mathrm{AA} 7075+10 \%$ vol SiC $\mathrm{P}-\mathrm{T} 6$ composite.

\section{MATERIAL PREPARATION AND FRICTION WELDING}

Aluminium alloy AA7075 was selected as a matrix material whose chemical composition is given in the Table 1 and for reinforcement ceramic material $\mathrm{SiC}$ particulate was selected [10]. The AA7075 $+10 \%$ vol $\mathrm{SiC}_{\mathrm{p}}$-T6 metal matrix composite was prepared using the stir casting method.

Table 1. Chemical composition of AA7075

\begin{tabular}{|c|c|c|c|c|c|c|c|c|c|}
\hline Element & $\mathrm{Cr}$ & $\mathrm{Cu}$ & $\mathrm{Fe}$ & $\mathrm{Mg}$ & $\mathrm{Mn}$ & $\mathrm{Si}$ & $\mathrm{Ti}$ & $\mathrm{Zn}$ & $\mathrm{Al}$ \\
\hline $\begin{array}{c}\text { Composition } \\
\text { wt.\% }\end{array}$ & 0.20 & 1.8 & 0.4 & 2.5 & 0.12 & 0.025 & 0.05 & 5.5 & Balance \\
\hline
\end{tabular}

The microstructure of the specimen in Fig. 1., shows the uniform distribution of the composite particles in the metal matrix aluminium alloy AA7075 + $10 \%$ vol $\mathrm{SiC}_{\mathrm{P}}$-T6.

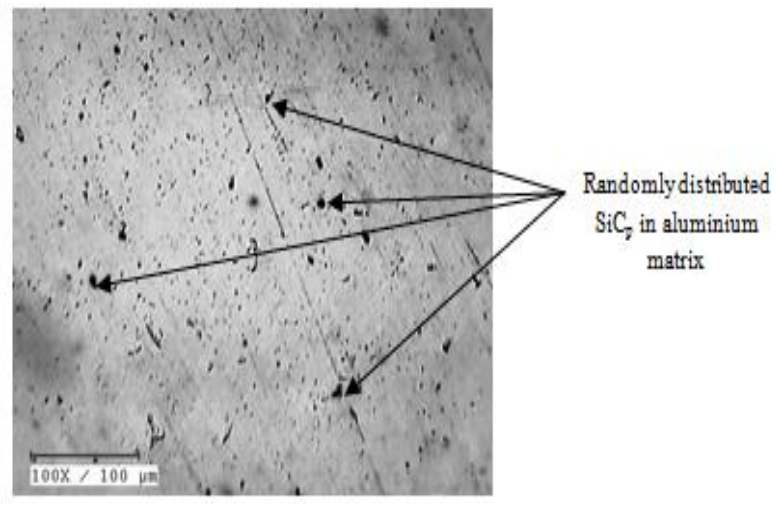

Fig. 1. Microstructure of the AA7075 + $10 \%$ vol $\mathrm{SiC}_{\mathrm{p}}$-T6

Friction welding on the cast rods of $\mathrm{AA} 7075+10 \%$ vol SiC $\mathrm{P}-\mathrm{T} 6$ had been done on the continues drive friction welding using the Taguchi's $\mathrm{L}_{27}$ orthogonal array framed by taking the four process parameters such SS, FP, UP and BOL with three level in each of them [11] as shown in the Table 2. The samples were then friction welded as per the Taguchi's $\mathrm{L}_{27}$ orthogonal array shown in the Table 3.

Table 2. Friction welding process parameters with levels for framing L27 orthogonal array

\begin{tabular}{|c|c|c|c|c|}
\hline & $\begin{array}{c}\text { Spindle } \\
\text { speed, } \\
\text { rpm }\end{array}$ & $\begin{array}{c}\text { Friction } \\
\text { pressure, } \\
\text { MPa }\end{array}$ & $\begin{array}{c}\text { Upset } \\
\text { pressure, } \\
\text { MPa }\end{array}$ & $\begin{array}{c}\text { Burn off } \\
\text { length, mm }\end{array}$ \\
\hline Level 1 & A1-1200 & B1-50 & C1-150 & D1-1 \\
\hline Level 2 & A2-1500 & B2-75 & C2-200 & D2-2 \\
\hline Level 3 & A3-1800 & B3-100 & C3-250 & D3-3 \\
\hline
\end{tabular}

As the application of AA7075 is predominantly found in the marine environment, to predict the strength of the friction welded joints tensile test was conducted. In the course of marine application, the material will be subjected to corrosion and as the hardness of the material got a direct impact on the resistance towards corrosion the hardness test was performed on the friction welded joints.

The welded samples were machined as shown in Fig. 2. along its axis according to ASTM B557M standard size. The ultimate tensile strength was predicted using the tensile test machine with the make of associated scientific engineering works having 5 ton loading capacity and integrated with digital encoder. The fractured specimen after the tensile test is shown in Fig. 3.
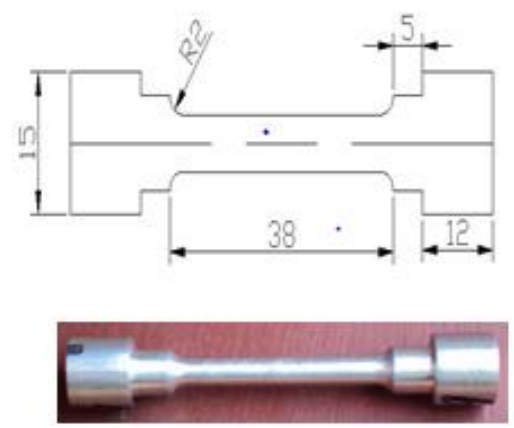

Fig. 2. Tensile test specimen

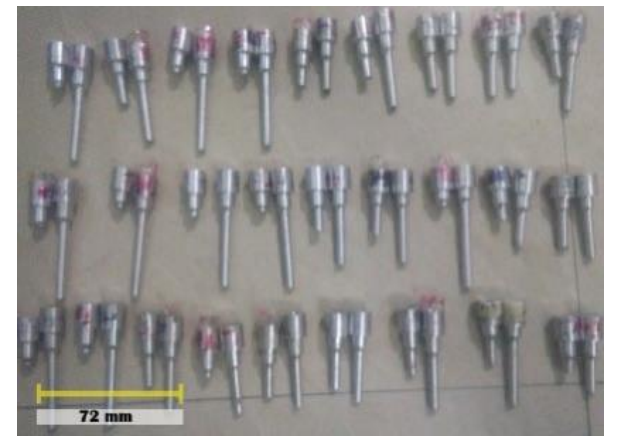

Fig. 3. Tensile test fractured specimens

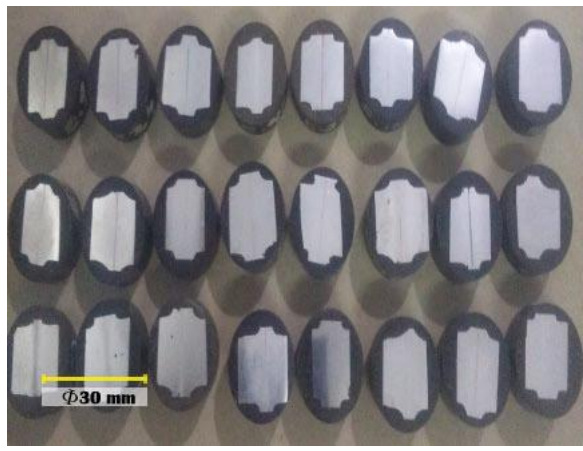

Fig. 4. Vicker's hardness test specimens

The Vickers microhardness tester of Wilson Wolpert make with loading capacity ranging between $10 \mathrm{~g}$ to $1 \mathrm{~kg}$ was used. The Vickers's hardness in the weld centre was measured after etching using Keller's reagent on the mould obtained by cutting the welded specimen along its radius in the welded zone as shown in Fig. 4. All the values of ultimate tensile strength and the hardness are tabulated in the Table 3 . 
Table 3. Experimental result for the ultimate tensile strength and hardness

\begin{tabular}{|c|c|c|c|c|c|c|}
\hline Ex. No. & $\begin{array}{c}\text { Spindle } \\
\text { speed, rpm }\end{array}$ & $\begin{array}{c}\text { Friction pressure, } \\
\mathrm{MPa}\end{array}$ & Upset pressure, $\mathrm{MPa}$ & $\begin{array}{l}\text { Burn off length, } \\
\text { mm }\end{array}$ & $\begin{array}{c}\text { Ultimate tensile } \\
\text { strength, MPa }\end{array}$ & Hardness \\
\hline 1 & 1200 & 50 & 150 & 1 & 205.305 & 124.456 \\
\hline 2 & 1200 & 50 & 200 & 2 & 198.456 & 138.11 \\
\hline 3 & 1200 & 50 & 250 & 3 & 192.119 & 152.654 \\
\hline 4 & 1200 & 75 & 150 & 1 & 224.025 & 137.521 \\
\hline 5 & 1200 & 75 & 200 & 2 & 217.828 & 147.228 \\
\hline 6 & 1200 & 75 & 250 & 3 & 222.766 & 155.557 \\
\hline 7 & 1200 & 100 & 150 & 1 & 243.338 & 132.342 \\
\hline 8 & 1200 & 100 & 200 & 2 & 248.983 & 146.671 \\
\hline 9 & 1200 & 100 & 250 & 3 & 240.123 & 161.212 \\
\hline 10 & 1500 & 50 & 150 & 3 & 206.893 & 122.975 \\
\hline 11 & 1500 & 50 & 200 & 1 & 200.34 & 137.604 \\
\hline 12 & 1500 & 50 & 250 & 2 & 192.234 & 148.453 \\
\hline 13 & 1500 & 75 & 150 & 3 & 225.456 & 129.658 \\
\hline 14 & 1500 & 75 & 200 & 1 & 199.234 & 138.457 \\
\hline 15 & 1500 & 75 & 250 & 2 & 223.456 & 154.076 \\
\hline 16 & 1500 & 100 & 150 & 3 & 245.987 & 130.121 \\
\hline 17 & 1500 & 100 & 200 & 1 & 251.87 & 145.19 \\
\hline 18 & 1800 & 100 & 250 & 2 & 248.45 & 159.51 \\
\hline 19 & 1800 & 50 & 150 & 2 & 211.123 & 121.494 \\
\hline 20 & 1800 & 50 & 200 & 3 & 203.298 & 135.553 \\
\hline 21 & 1800 & 50 & 250 & 1 & 196.87 & 147.252 \\
\hline 22 & 1800 & 75 & 150 & 2 & 229.374 & 126.517 \\
\hline 23 & 1800 & 75 & 200 & 3 & 222.87 & 138.126 \\
\hline 24 & 1800 & 75 & 250 & 1 & 226.09 & 152.595 \\
\hline 25 & 1800 & 100 & 150 & 2 & 250.098 & 129.358 \\
\hline 26 & 1800 & 100 & 200 & 3 & 253.112 & 143.709 \\
\hline 27 & 1800 & 100 & 250 & 1 & 247.129 & 158.218 \\
\hline
\end{tabular}

\subsection{Regression equation}

Regression equation is the mathematical model developed to predict the output parameter through input parameters. The regression equation for the UTS and HD values were developed using the friction welding process parameters SS, FP, UP and BOL using the values in Table 3 and shown in Eq. 1 and Eq. 2.

$U T S=149+0.00871 S S+0.939 F P-0.0582 U P+1.02 B O L$

$H D=88.5+0.00795 S S+0.173 F P-0.261 U P+0.226 B O L$

The accuracy of the obtained output can be found by predicting the $\mathrm{R}^{2}$ value for the regression equation. Higher value of $\mathrm{R}^{2}$ means good result. Here in this work the $\mathrm{R}^{2}$ value obtained for UTS is $92.3 \%$ and HD is $97.2 \%$, which clearly shows that the UTS and HD values found through testing are having high accuracy.

\section{GREY RELATIONAL ANALYSIS}

Grey relational analysis is one of the most powerful statistical analysis tool for solving problems with complex correlations and multiple factors and variables [12]. Here the concept of solving is based on combination of all the contributing attributes into a single combined attribute [13]. Thus a problem is reduced to a single objective decision making problem [14]. Grey relational analysis based on Taguchi's design of experiments is used to obtain optimised characteristic process parameters for any problem [15].
Here grey relational analysis was used to obtain the optimum process parameters for the friction welding process on aluminium metal matrix composite (AA7075 + $10 \%$ vol SiC $\mathrm{P}_{\mathrm{P}} \mathrm{T} 6$ ). The influencing parameters for the process were selected and various levels of input characteristics were considered [16]. Initially the multiresponse characteristics was normalised into a single attribute to obtain the grey relational coefficient $(\tau)$ and eventually the grey relational grading $(\delta)$ [17]. Once the grey coefficient was obtained, the parameters were analysed both theoretically by ANOVA and experimentally [18]. The congruence between the two provides the conformation of the optimum parameters. The GRA process is explicitly explained through flow chart shown in Fig. 5.

\subsection{Normalizing the results}

The raw data obtained through experimentation is suitably converted through normalizing for performing grey relational analysis. The normalizing of the objective functions is essential for combining the various objectives with different units to obtain a single objective function. Therefore, a linear normalisation of the experimental results hardness and ultimate tensile strength obtained for the friction welded $\mathrm{AA} 7075+10 \%$ vol $\mathrm{SiC}_{\mathrm{p}}$-T6 metal matrix composite was performed in the range between 0 and 1 . A higher normalized values infers betterment in the performance. The optimum normalized result would be equal to 1 and the normalisation is done through Eq. 3 . The normalised value of the ultimate tensile strength and hardness is shown in column 4 and 5 of Table 4 respectively. 


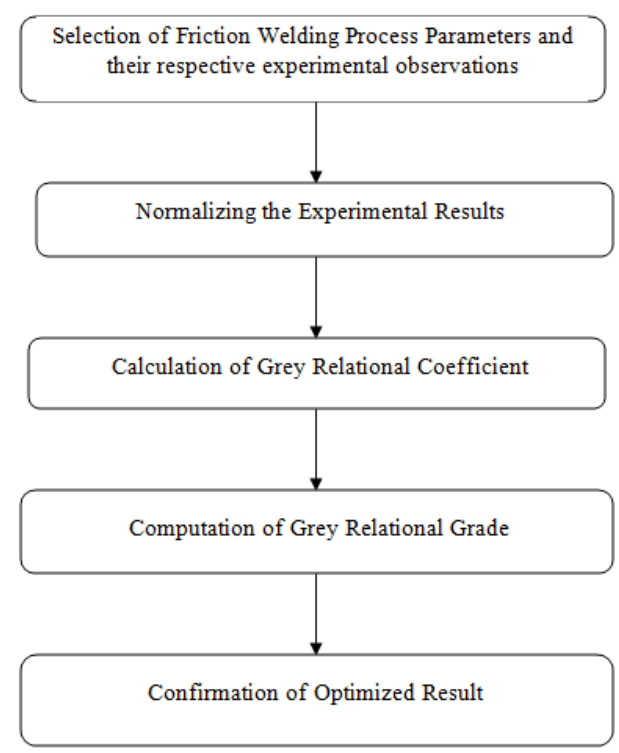

Fig. 5. Flowchart-GRA process

$\alpha_{x y}=\frac{\left(\beta_{x y}-\min _{y} \beta_{x y}\right)}{\left(\max _{y} \beta_{x y}-\min _{y} \beta_{x y}\right)}$,

where, $\alpha_{x y}$ is the normalized value; $\beta_{x y}$-the $\mathrm{x}^{\text {th }}$ experimental results in the $y^{\text {th }}$ experiment.

\subsection{CALCULATION OF GREY RELATIONAL COEFFICIENT}

The grey relational coefficient was calculated using Eq. 4 to know the actual variation between the normalised result and the ideal result. The higher value of grey relational coefficient infers that the normalised result is closer to the ideal result. The distinguishing coefficient's purpose is to vary the range of the grey relational coefficient and therefore this can be adjusted based on the requirement. Although different distinguishing coefficients would yield different result but the rank of the all the grey relation coefficients obtained using distinguishing coefficients would remain the same. The value of the grey relational coefficients is listed in column 6 and 7 of Table 4 .

$\tau=\frac{\left(\min _{x} \min _{y}\left|\alpha_{x}^{0}-\alpha_{x y}\right|+\lambda \max _{x} \max _{y}\left|\alpha_{x}^{0}-\alpha_{x y}\right|\right)}{\left(\left|\alpha_{x}^{0}-\alpha_{x y}\right|+\lambda \max _{x} \max _{y}\left|\alpha_{x}^{0}-\alpha_{x y}\right|\right)}$,

where, $\tau$ is the grey relational coefficient; $\alpha_{x}^{0}$ is the ideal normalized result for the $x^{\text {th }}$ performance characteristic; $\lambda$ is the distinguishing coefficient, $(0 \leq \lambda \leq 1)$ for this study $\lambda=0.5$.

\subsection{Computation of grey relational grade}

Grey relational grade is the average of the grey relational coefficient for each performance characteristic. The Grey Relational Grade for each experiment had been found out by performing $\mathrm{L}_{27}$ orthogonal array using the Eq. 5 and the values obtained are listed in column 8 of Table 4 .

Table 4. Normalised values and grey coefficients and grade values for hardness and UTS

\begin{tabular}{|c|c|c|c|c|c|c|c|}
\hline \multirow{2}{*}{ Ex. No } & \multicolumn{2}{|c|}{ Response values } & \multicolumn{2}{|c|}{ Normalized values } & \multicolumn{2}{|c|}{ Grey relational coefficients } & \multirow{2}{*}{$\begin{array}{c}\text { Grey } \\
\text { relationa } \\
\text { grade }\end{array}$} \\
\hline & UTS, MPa & Hardness & UTS & Hardness & UTS & Hardness & \\
\hline Col 1 & Col 2 & Col 3 & $\mathrm{Col} 4$ & Col 5 & Col 6 & Col 7 & Col 8 \\
\hline 1 & 205.305 & 124.456 & 0.370119 & 0.074576 & 0.216189 & 0.350773 & 0.389465 \\
\hline 2 & 198.456 & 138.11 & 0.410198 & 0.418349 & 0.103897 & 0.462256 & 0.35814 \\
\hline 3 & 192.119 & 152.654 & 0.516088 & 0.784531 & 0 & 0.698842 & 0.333333 \\
\hline 4 & 224.025 & 137.521 & 0.483916 & 0.40352 & 0.523109 & 0.456005 & 0.511828 \\
\hline 5 & 217.828 & 147.228 & 0.525204 & 0.647918 & 0.421507 & 0.586798 & 0.46361 \\
\hline 6 & 222.766 & 155.557 & 0.639797 & 0.857621 & 0.502467 & 0.778357 & 0.501237 \\
\hline 7 & 243.338 & 132.342 & 0.582415 & 0.273126 & 0.839752 & 0.40754 & 0.757291 \\
\hline 8 & 248.983 & 146.671 & 0.729025 & 0.633894 & 0.932304 & 0.577297 & 0.880753 \\
\hline 9 & 240.123 & 161.212 & 0.850651 & 1 & 0.787041 & 1 & 0.701303 \\
\hline 10 & 206.893 & 122.975 & 0.369679 & 0.037288 & 0.242225 & 0.341831 & 0.397527 \\
\hline 11 & 200.34 & 137.604 & 0.411559 & 0.40561 & 0.134786 & 0.456875 & 0.366243 \\
\hline 12 & 192.234 & 148.453 & 0.471294 & 0.67876 & 0.001885 & 0.608836 & 0.333753 \\
\hline 13 & 225.456 & 129.658 & 0.455344 & 0.205549 & 0.546571 & 0.386264 & 0.524423 \\
\hline 14 & 199.234 & 138.457 & 0.413731 & 0.427086 & 0.116653 & 0.466021 & 0.361442 \\
\hline 15 & 223.456 & 154.076 & 0.621321 & 0.820333 & 0.51378 & 0.735655 & 0.506986 \\
\hline 16 & 245.987 & 130.121 & 0.600194 & 0.217206 & 0.883183 & 0.389774 & 0.810614 \\
\hline 17 & 251.87 & 145.19 & 0.757168 & 0.596606 & 0.979637 & 0.553468 & 0.960868 \\
\hline 18 & 248.45 & 159.51 & 0.894231 & 0.957148 & 0.923565 & 0.921061 & 0.8674 \\
\hline 19 & 211.123 & 121.494 & 0.377029 & 0 & 0.311577 & 0.333333 & 0.420726 \\
\hline 20 & 203.298 & 135.553 & 0.408011 & 0.35397 & 0.183283 & 0.436289 & 0.379732 \\
\hline 21 & 196.87 & 147.252 & 0.469403 & 0.648522 & 0.077894 & 0.587214 & 0.351591 \\
\hline 22 & 229.374 & 126.517 & 0.463166 & 0.126467 & 0.610808 & 0.364025 & 0.562308 \\
\hline 23 & 222.87 & 138.126 & 0.482262 & 0.418752 & 0.504173 & 0.462429 & 0.502095 \\
\hline 24 & 226.09 & 152.595 & 0.613799 & 0.783045 & 0.556966 & 0.697394 & 0.530203 \\
\hline 25 & 250.098 & 129.358 & 0.647041 & 0.197996 & 0.950584 & 0.384023 & 0.910058 \\
\hline 26 & 253.112 & 143.709 & 0.765765 & 0.559318 & 1 & 0.531529 & 1 \\
\hline 27 & 247.129 & 158.218 & 0.852489 & 0.924619 & 0.901907 & 0.868989 & 0.83599 \\
\hline
\end{tabular}


The grey relational grade predicts about the significance of each performance characteristic on the output of the experiment. Also this would give us an insight about the optimum level of these multiple performance parameters in order to get the best possible output. Greater value of grey relational grade indicates a stronger relationship between the parameters and also that the experimental results are closer to the ideal results.

$\delta_{y}=\frac{1}{z \sum_{x=1}^{Z} \tau_{x y}}$

where, $\delta_{\mathrm{y}}$ is the grey relational grade for the $y^{\text {th }}$ experiment; $z$ is the number of performance characteristics.

\subsection{Determining the most significant process parameter}

The parameter which affects the responses in the experiment based on the average grey relational grade at various levels had been determined by finding the difference between maximum and minimum values of the grey relational grade. Higher this difference indicates higher significance of the particular performance parameter on the output result of the experiment and it is clearly shown in Table 5. The friction pressure was found to be the most significant friction welding process parameter during friction welding of $\mathrm{AA} 7075+10 \%$ vol SiC $\mathrm{P}_{\mathrm{P}}$-T6 metal matrix composite.

Table 5. Grey relational grade for each process parameter combination

\begin{tabular}{|c|c|c|c|c|c|}
\hline \multirow{2}{*}{$\begin{array}{c}\text { Process } \\
\text { parameter }\end{array}$} & \multicolumn{5}{|c|}{ Grey relational grade } \\
\hline & Level 1 & Level 2 & Level 3 & Max-Min & Rank \\
\hline $\begin{array}{l}\text { Spindle } \\
\text { speed, } \\
\text { rpm }\end{array}$ & 0.56749 & 0.554947 & 0.564329 & 0.012543 & 4 \\
\hline $\begin{array}{c}\text { Friction } \\
\text { pressure, } \\
\mathrm{MPa}\end{array}$ & 0.54078 & 0.553295 & 0.582647 & 0.041867 & 1 \\
\hline $\begin{array}{c}\text { Upset } \\
\text { pressure, } \\
\mathrm{MPa}\end{array}$ & 0.542506 & 0.558332 & 0.576023 & 0.033517 & 2 \\
\hline $\begin{array}{c}\text { Burn off } \\
\text { length, } \\
\text { mm }\end{array}$ & 0.551093 & 0.569645 & 0.555753 & 0.018552 & 3 \\
\hline
\end{tabular}

\subsection{Confirmation}

It is essential to predict and to verify the improvement of the performance characteristics using the optimum level of machining parameters that is obtained in the previous step using the Eq. 6.

Predicted grey relational grade:

$\hat{\delta}=\delta_{m}+\sum_{x=1}^{n}\left(\delta_{y}-\delta_{m}\right)$

where, $\delta_{m}$ is the mean grey relational grade; $\delta_{y}$ is the mean grey relational grade at optimum level; $n$ is the number of parameters that significantly affect the multi performance characteristics.

\section{ANALYSIS OF VARIANCE (ANOVA)}

The statistical tool used to determine the impact of the parameters on the process performance is the analysis of variance [19]. Variance is the measure as to find how every individual widely vary in a group. The analysis of variance provides the contribution of each parameter towards the inappropriate performance [20]. This is done by incorporating the sum of squares method, where Sum of Squares (SS) is the sum of squared differences from the mean of the grey relational grade $\left(\gamma_{m}\right)$. The Total Sum of Squares of grey relational grade (TSS) can be calculated from:

TSS $=\sum_{k=1}^{l}\left(\gamma_{l}-\gamma_{m}\right)^{2}$,

where, TSS is the total sum of squares; $K$ is the number of experiments in the orthogonal array; $\gamma_{l}$ is the mean grey relational grade for the $k^{\text {th }}$ experiment.

The Mean Sum of Squares (MSS) is the ratio of SS of each parameter to the degree of freedom of that particular process parameter. The mean square is also found for the Sum of Squares of error (SSE), which is a part of the total SS. Further the F-Test (Fisher's test) is used to find which parameter has the most significant effect on the process performance [21]. The parameter with large $\mathrm{F}$ value has the most significant value [22]. The ANOVA result is shown in Table 6.

Table 6. ANOVA

\begin{tabular}{|c|c|c|c|c|c|c|}
\hline Source & DF & Seq SS & Adj SS & Adj MS & F & $\% \mathrm{C}$ \\
\hline SS & 2 & 0.000766 & 0.000766 & 0.000383 & 0.47 & 0.1185 \\
\hline FP & 2 & 0.481204 & 0.481204 & 0.240602 & 295.69 & 74.5431 \\
\hline UP & 2 & 0.142846 & 0.142846 & 0.071423 & 87.77 & 22.1267 \\
\hline BOL & 2 & 0.020740 & 0.020740 & 0.010370 & 12.74 & 3.2117 \\
\hline Error & 18 & 0.014647 & 0.014647 & 0.000814 & - & - \\
\hline Total & 26 & 0.660204 & - & - & - & - \\
\hline
\end{tabular}

The results of the analysis of variance shows that the most significant factor is Friction Pressure (FP).

\subsection{Confirmation experiment}

The result of the ANOVA provides the significant parameters and contributions. The response table provides the optimum working parameters, based on the values of the grey relational grade. The obtained optimum parameters are experimentally verified and validated using the estimated grey relational grade using the Eq. 8 and it is shown in Table 7.

$\widehat{\gamma}=\gamma_{m}+\sum_{i=1}^{q}\left(\bar{\gamma}_{k}-\gamma_{m}\right)$,

where, $\gamma_{m}$ is the total mean of grey relational grade; $\bar{\gamma}_{k}$ is the mean of the grey relational grade at the optimum level.; $q$ is the total number of significant parameters that affect the process performance.

The values of the output parameters for the best result obtained from the grey relational grade in Table 5 are compared with optimum result as predicted from Table 7 . The optimum combination of the parameters was found to be $A_{1} B_{3} C_{3} D_{2}$. The predicted result is experimentally validated and deviation was found to be within the acceptable range. 
Table 7. Comparison result of initial and optimum combination of process parameters

\begin{tabular}{|l|c|c|c|}
\hline \multirow{2}{*}{$\begin{array}{l}\text { List of } \\
\text { parameters }\end{array}$} & \multirow{2}{*}{$\begin{array}{c}\text { Initial } \\
\text { machining } \\
\text { parameters }\end{array}$} & \multicolumn{2}{|c|}{$\begin{array}{c}\text { Optimum machining } \\
\text { parameters }\end{array}$} \\
\cline { 3 - 4 } & $\mathrm{A}_{1} \mathrm{~B}_{1} \mathrm{C}_{1} \mathrm{D}_{1}$ & $\mathrm{~A}_{1} \mathrm{~B}_{3} \mathrm{C}_{3} \mathrm{D}_{2}$ & $\mathrm{~A}_{1} \mathrm{~B}_{3} \mathrm{C}_{3} \mathrm{D}_{2}$ \\
\hline Setting level & 124.456 & 145.0464 & 147.4 \\
\hline Hardness & 205.305 & 227.586 & 228.3 \\
\hline UTS, MPa & 0.370119 & 0.609 & 0.613 \\
\hline $\begin{array}{l}\text { Grey relation } \\
\text { grade }\end{array}$ & 0.36 & \\
\hline
\end{tabular}

\section{RESULTS AND DISCUSSION}

When the welded AA7075-10\% vol $\mathrm{SiC}_{\mathrm{P}}$ reinforced metal matrix composite materials are subjected to tensile loading, the distributed particles will be receiving the stress. As the stress value develops around the particles, it reaches a critical value after which the particles will be unable to withstand the stress and it fractures or gets decohesion from the aluminium metal matrix. This mechanism creates internal defects leading to increase in the voids causing in reduction the ductility of the material. In tensile test the gauge length of the specimen undergoes uniform deformation but during hardness measurement in the welded metal matrix composite the localized region below the indenter where the concentration of $\mathrm{SiC}_{\mathrm{P}}$ is high due to the friction welding effect only gets plasticized. When the indenter load gets applied on the SiC particle, they do not experience the fracture as in the case of tensile test resulting in a strengthening effect and that gets reflected in the hardness value. So only variation in linear relationship between the UTS and hardness value is seen in the friction welded metal matrix composite which is in contrast with that of the monolithic material [23].

\subsection{MICROSTRUCTURE}

The microscopic image of the weldment produced under optimized friction welding parameter is shown in Fig. 6.

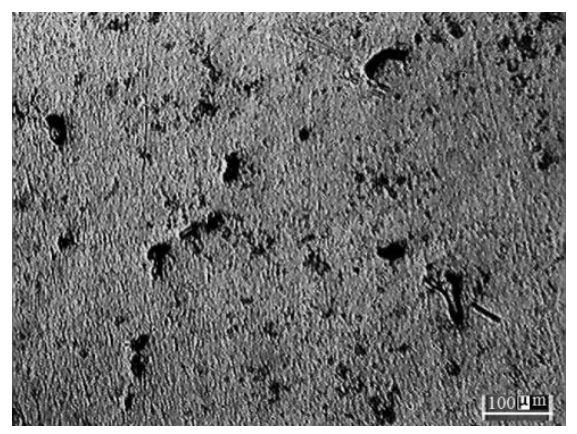

Fig. 6. Microstructure of the friction weld zone

Unlike the non-welded AA7075 - $10 \%$ vol SiC -T6 during the friction welding process the $\mathrm{SiC}$ particles in the weld zone breaks down to smaller size [24] and get distributed all over the weld zone thereby increasing its strength and at that same time in some region agglomeration of the $\mathrm{SiC}$ particles will also take place eventually causing increase in hardness. To predict the type of failure of the fractured surface of the friction welded AA7075-10\% vol $\mathrm{SiC}_{\mathrm{p}}$-T6 with the optimised process parameters, Scanning Electron Microscope (SEM) study had been applied. It had been predicted that the fractured surface in the Fig. 7. shows dimples and cleavage to represent ductile-brittle failure and it is in supportive with the objective to achieve high ultimate tensile strength and hardness. As the optimized friction welding parameters are having higher levels of friction pressure and upsetting pressure, work hardening happens in the weld zone because of which it has been observed that percentage increase in hardness value is found to be more when compared with that of percentage increase in UTS value [25].

Fig. 8. shows the SEM image of the fractured surface of specimen (Ex.No.7) which has given high UTS value, shows a ductile failure as shallow dimples are seen. The SEM image of the fractured surface of specimen (Ex.No.26) which has given low UTS, has predominantly shown larger dimples with more cleavages confirming a brittle failure and it is shown in Fig. 9.

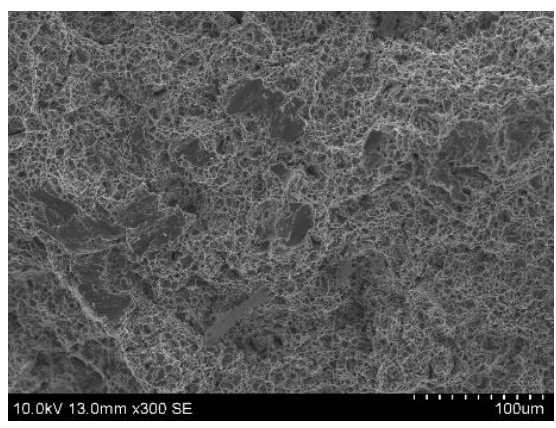

Fig. 7. Microstructure of the fractured surface

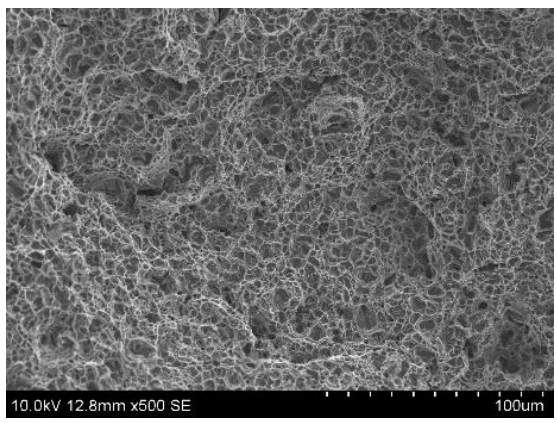

Fig. 8. SEM image of high UTS specimen

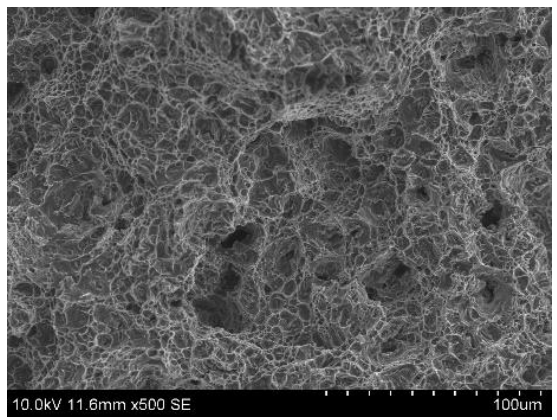

Fig. 9. SEM image of low UTS specimen

\section{CONCLUSIONS}

From this work, it has been firmly proved that the grey relational analysis is the effective optimisation tool for 
friction welding of the AA7075-10\% vol SiC $\mathrm{S}_{\mathrm{P}} \mathrm{T} 6$ welded joints. The following were the results obtained:

1. It had been found that the optimal combination of friction welding process parameters for combined objective of enhanced UTS and HD through grey relational analysis is spindle speed $1200 \mathrm{rpm}$, friction pressure $100 \mathrm{MPa}$, upset pressure $250 \mathrm{MPa}$, burn off length $2 \mathrm{~mm}$.

2. An impressive improvement in hardness by $20 \%$ and in ultimate tensile strength by $13.78 \%$ was observed.

3. The SEM image of the fractured surface also revealed good compliance with objective by showing ductilebrittle failure.

4. This research work proves that using grey relational concept for optimising multi response problems yields best result as the difference between the predicted value and experimental value is found to be very less.

5. Analysis of variance proved that the friction pressure is the most significant parameter for friction welding AA7075 - $10 \%$ vol SiC $\mathrm{P}_{\mathrm{P}}$-T6 joints by contributing about $74 \%$, followed by upset pressure about $22.7 \%$.

\section{REFERENCES}

1. Prater, T. Solid State Joining of Metal Matrix Composites: A Survey of Challenges and Potential Solution Materials and Manufacturing Processes 26 (4) 2011: pp. 636-648. https://doi.org/10.1080/10426914.2010.492055

2. Bozkurt, Y., Kentli, A., Uzun, H., Salman, $\mathbf{S}$. Experimental Investigation and Prediction of Mechanical Properties of Friction Stir Welded Aluminium Metal Matrix Composite Plates Materials Science (Medžiagotyra) 18 (4) 2012: pp. 336-340. http://dx.doi.org/10.5755/j01.ms.18.4.3092

3. Jangara, K.K., Sharma, N., Khanna, R., Matta, D. An Experimental Investigation and Optimisation of Friction Welding Process for AA6082 T6 (Cryogenic Treated and Untreated) Using an Integrated Approach of Taguchi, Grey Relational Analysis and Entropy Method Proceedings of Institution of Mechanical Engineering Part L: Journal of Materials:Design and Application 230 (2) 2016: pp. 454-469.

4. Arunachalam, S., Perumal, S. Investigation of Effect of Graphite Particles on Drillability of Metal Matrix Composite Materials Science (Medžiagotyra) $22(3)$ 2016: pp. 390-396. http://dx.doi.org/10.5755/j01.ms.22.3.9724

5. Khalid Rafi, H., Janaki Ram, G.D., Phanikumar, G., Prasad Rao, K. Microstructure and Tensile Properties of Friction Welded Aluminium Alloy AA7075-T6 Materials and Design 31 2010: pp. 2375-80.

https://doi.org/10.1016/j.matdes.2009.11.065

6. Kuo, C.C., Liao, H.Y. Dimensional Accuracy Optimization of the Micro-Plastic Injection Molding Process Using the Taguchi Design Method Materials Science (Medžiagotyra) 21 (2) 2015: pp. 244-248. http://dx.doi.org/10.5755/j01.ms.21.2.5864

7. Gargasas, J., Valiulis, A.V., $\quad$ Gedzevicius, I., Mikaliunas, S., $\quad$ Nagurnas, S., $\quad$ Pokhmurska, $H$. Optimization of the Arc Spraying Process Parameters of the Fe-Base Mn-Si-Cr-Mo-Ni Coatings for the Best Wear Performance Materials Science (Medžiagotyra) 22 (1) 2016: pp. 20-24.
8. Ramesh, S., Viswanathan, R., Ambika, S. Measurement and Optimization of Surface Roughness And Tool Wear Via Grey Relational Analysis, TOPSIS and RSA Techniques Measurement 78 2016: pp. 63-72.

https://doi.org/10.1016/j.measurement.2015.09.036

9. Satish Kumar, S., Asokan, P. Selection of Optimal Conditions for CNC Multitool Drilling System Using NonTraditional Techniques International Journal of Machining and Machinability of Materials 3 2008: pp. $190-207$. https://doi.org/10.1504/IJMMM.2008.017633

10. Chenga, N.P., Zenga, S.M., Liua, Z.Y. Preparation, Microstructures and Deformation Behaviour of SiCp/6066Al Composites Produced by PM Route Journal of Materials Processing Technology 202 2008: pp. $27-40$. https://doi.org/10.1016/j.jmatprotec.2007.08.044

11. Shanjeevi, C., Satish Kumar, S., Sathiya, P. MultiObjective Optimization of Friction Welding Parameters in AISI 304L Austenitic Stainless Steel and Copper Joints Proceedings of the Institution of Mechanical Engineers, Part B: Journal of Engineering Manufacture 230 2014: pp. 449-457. https://doi.org/10.1177/0954405414555590

12. Patil, P.J, Patil, C.R. Analysis of Process Parameters in Surface Grinding Using Single Objective Taguchi and Multi-Objective Grey Relational Grade Perspectives in Science 8 2016: pp. 367-369. https://doi.org/10.1016/j.pisc.2016.04.077

13. Ghosh, N., Pal, P.K., Nandi, G. Parametric Optimization of MIG Welding on 316L Austenitic Stainless Steel by Grey-Based Taguchi Method Procedia Technology 25 2016: pp. $1038-1048$. https://doi.org/10.1016/j.protcy.2016.08.204

14. Saravanan Sivam, P., Antony Michaelraj, L., Satish Kumar, S., Prabhakaran, G., Dinakaran, D., Ilankumaran, V. Statistical Multi-Objective Optimization of Electrical Discharge Machining Parameters in Machining Titanium Grade 5 Alloy Using Graphite Electrode Proceedings of the Institution of Mechanical Engineers, Part B: Journal of Engineering Manufacture 228 2013: pp. 736-743. https://doi.org/10.1177/0954405413511073

15. Zuo, W., Jiaqiang, E., Liu, X., Peng, Q., Deng, Y., Zhu, H. Orthogonal Experimental Design and Fuzzy Grey Relational Analysis for Emitter Efficiency of the MicroCylindrical Combustor with a Step Applied Thermal Engineering 103 2016: pp. 945-951. https://doi.org/10.1016/j.applthermaleng.2016.04.148

16. Lohithaksha, M.M., Ramanujam, R., Venkatesan, K., Jerald, J. Optimization of Machining Parameters for End Milling of Inconel 718 Super Alloy Using Taguchi Based Grey Relational Analysis Procedia Engineering 64 2013: pp. $1276-1282$. https://doi.org/10.1016/j.proeng.2013.09.208

17. Chamoli, S., Yu, P., Kumar, A. Multi Response Optimization of Geometric and Flow Parameters in a Heat Exchanger Tube with Perforated Disk Inserts by Taguchi Grey Relational Analysis Applied Thermal Engineering 103 2016: pp. 1339-1350. https://doi.org/10.1016/j.applthermaleng.2016.04.166

18. Singh, T., Patnaik, A., Chauhan, R. Optimization of Tribological Properties of Cement Kiln Dust-Filled Brake Pad Using Grey Relation Analysis Materials and Design 89 2016: pp. 1335 - 1342. https://doi.org/10.1016/j.matdes.2015.10.045 
19. Ratnam, Ch., Arun Vikram, K., Ben, Bs., Murthy, Bsn. Process Monitoring and Effects of Process Parameters on Responses in Turn-Milling Operations Based on SN Ratio and ANOVA Measurement 94 2016: pp. 221-232. https://doi.org/10.1016/j.measurement.2016.07.090

20. Nandagopal, K., Kailasanathan, C. Analysis of Mechanical Properties and Optimization of Gas Tungsten Arc Welding (GTAW) Parameters on Dissimilar Metal Titanium (6AL-4v) and Aluminium 7075 by Taguchi and ANOVA Techniques Journal of Alloys and Compounds 682 2016: pp. $503-516$. https://doi.org/10.1016/j.jallcom.2016.05.006

21. Narender Singh, P., Raghukandan, K., Pai, B.C. Optimization by Grey Relational Analysis of EDM Parameters on Machining $\mathrm{Al}-10 \% \mathrm{SiCP}$ Composites Journal of Materials Processing Technology 155--56 2004: pp. $1658-1661$. https://doi.org/10.1016/j.jmatprotec.2004.04.322

22. Pandiarajan, S.,

Senthil Kumaran, $\mathbf{S}$. Kumaraswamidhas, L., Saravanan, R. Interfacial Microstructure and Optimization of Friction Welding by Taguchi and ANOVA method on SA 213 Tube to SA 387
Tube Plate Without Backing Block Using an External Tool Journal of Alloys and Compounds 654 2016: pp. 534-545. https://doi.org/10.1016/j.jallcom.2015.09.152

23. Kozola, B.D., Shen, Y.L. A Mechanistic Analysis of the Correlation Between Overall Strength and Indentation Hardness in Discontinuously Reinforced Aluminium Journal of Materials Science 38 2003: pp. 901 - 907. https://doi.org/10.1023/A:1022304621161

24. Hascalik, A., Orhan, N. Effect of Particle Size on the Friction Welding of $\mathrm{Al}_{2} \mathrm{O}_{3}$ Reinforced $6160 \mathrm{Al}$ Alloy composite and SAE 1020 Steel Materials \& Design 28 2007: pp. 313-317. https://doi.org/10.1016/j.matdes.2005.06.001

25. Antonio, A.M., Mayer, A., Santos, J.F.D., Kwietniewski, C.E.F., Strohaecker, T.R. Mechanical and Metallurgical Properties of Friction-Welded TiC Particulate Reinforces Ti-6Al-4V Composites Science and Technology 64 2004: pp. 1495-1501. https://doi.org/10.1016/j.compscitech.2003.10.017 